\title{
EL EDIFICIO BARROCO DE LA IGLESIA DE SAN BERNARDO DE SEVILLA
}

\section{THE CHURCH OF SAN BERNARDO IN SEVILLE: A BAROQUE BUILDING}

\author{
Teodoro Falcón Márquez \\ Universidad de Sevilla. España \\ ORCID: 0000-0002-1300-708X \\ tfm@us.es
}

\begin{abstract}
En este artículo se analiza el proceso constructivo de la iglesia de San Bernardo de Sevilla, que marca la transición del barroco al neoclásico. Su edificación se llevó a cabo entre 1780 y 1785 bajo la dirección del arquitecto José Álvarez. Se publica la planta y sección longitudinal originales y comentamos los cambios de criterio experimentados con relación a ellos. Asimismo se documentan los materiales constructivos, así como los gastos de la construcción, además de los protagonistas que intervinieron en él, entre los que destaca el aparejador y arquitecto Fernando Rosales.

Palabras clave: arquitectura barroca; iglesia de San Bernardo; Sevilla; José Álvarez; Fernando Rosales.
\end{abstract}

This paper analyzes the construction process of the Church of San Bernardo, which marks the transition from Baroque to Neoclassicism. Its construction was carried out between 1780 and 1785 under the direction of the architect José Álvarez. We published the original plant and the longitudinal section and comment on the changes in criteria experienced in relation to them. The construction materials are also documented, in addition to the protagonists who intervened in it, among which the building engineer and architect Fernando Rosales stands out.

Keywords: Baroque architecture; Church of San Bernardo; Seville; José Álvarez; Fernando Rosales.

\section{LOS ORÍGENES DEL NUEVO TEMPLO Y SUS PRINCIPALES PROTAGONISTAS}

Noticias sobre los dos templos anteriores que hubo en este solar las dimos en otro artículo, en el que facilitamos algunos datos históricos sobre el barrio y los 
prolegómenos de la actual edificación ${ }^{1}$. En este analizamos su proceso constructivo, llevado a cabo entre 1780-1785. Se trata de la última iglesia sevillana del barroco, en su transición hacia el neoclasicismo. Se erigió en el curso de las mejoras llevadas a cabo en este sector oriental de la ciudad, a extramuros de la Puerta de la Carne, en donde se edificaron además la Real Fundición de Artillería y el antiguo Cuartel de Caballería (hoy Diputación Provincial). La Fundición, que tiene su origen en 1540, es el resultado de una serie de ampliaciones a lo largo del siglo XVIII, durante los reinados de Felipe V y Carlos III, cuando se convierte en Real Fundición de Cañones de bronce. Destacan las obras ejecutadas por los ingenieros Próspero Verbom e Ignacio Sala en 1725, la de Juan Manuel de Porres entre 1757-1759, la de Jean Maritz en 1767, y, finalmente, la del arquitecto Vicente de San Martín entre 1782-1786, coincidiendo con la edificación de este templo². La construcción definitiva del antiguo Cuartel de Caballería se debe al proyecto del ingeniero Antonio Hurtado (1785-1788), que se inició cuando la iglesia de San Bernardo concluía ${ }^{3}$.

Centrándonos en este templo comenzaremos por aquellos protagonistas que hicieron posible su edificación. Destacaremos en primer lugar a Marcelo Félix Doye Peellaeert, canónigo magistral y presidente de las capillas de la catedral. En virtud de ello formalizó todos los contratos de la obra y supervisó las cuentas del proceso constructivo, dotación de retablos, mobiliario, etc. ${ }^{4}$ Se trata de un sevillano de origen flamenco. Era hijo de Luis Doye, natural de la ciudad de Oudenarde, y de doña Isabel Peellaerts, natural de Sevilla, aunque de la misma procedencia. Doye fue bautizado en la iglesia del Sagrario de esta ciudad el 17 de enero de 1727 por el doctor Antonio Sánchez, cura de esa parroquia. Fue su padrino Lurino Leirens, vecino de esa collación. Sus datos biográficos constan en un amplio expediente sobre Pruebas de Sangre, que se inició en 20 de abril de 1755, a raíz de la pretensión de don Marcelo de ocupar la plaza de canónigo magistral de la catedral, vacante tras el fallecimiento del doctor Alfonso Texedor ${ }^{5}$. Doye fue

${ }^{1}$ Falcón Márquez, 2019: 27-40.

2 Sancho Corbacho, 1952: 231, nota 151. Rabanal Yus, 1988: 103-113. De la Vega Viguera, 1992. Mora Piris, 1994. Roig del Negro, 2001. Ollero Lobato, 2004: 439.

${ }^{3}$ Morales Sánchez, 1991, lám. 223. García Quilis, 1999: 829-840. Ponce Ortiz/Morales Sánchez, 2004.

${ }^{4}$ Por poner solo algunos ejemplos, diremos que Doye presentó al cabildo catedral los planos originales de esta iglesia, trazados por José Álvarez en 12 de mayo de 1780. En 6 de julio de 1783, el arquitecto mostró al presidente de las capillas el presupuesto de la solería. Archivo de la Catedral de Sevilla (ACS), sección VI, Contaduría, legajo 12.316, exp. nº 1 . En octubre de 1784, el canónigo pagó varias minutas durante la ejecución del retablo mayor al ensamblador Manuel Barrera y Carmona; al dorador del retablo, José Rico; y al escultor Blas Molner por la realización de varias tallas. ACS, Contaduría, legajo 12.317, exp. 2A. Estos pagos continuaban en abril de 1785. ACS, Contaduría, legajo 12.317, exp. $\mathrm{n}^{\circ} 3$.

5 ACS, sección I, Pruebas de Sangre, letra M, nº 38 A. 05202. 
quien bendijo solemnemente esta iglesia de San Bernardo el 19 de agosto de 1785, vísperas de la festividad del santo titular ${ }^{6}$, y contribuyó a dotar económicamente a varios templos de esta ciudad ${ }^{7}$. Asimismo fue miembro de la Real Academia Sevillana de Buenas Letras, en la que ingresó el 6 de febrero de 1756 y pronunció varios discursos, que se publicaron, alusivos a diversas devociones ${ }^{8}$. Como veremos más adelante, debió de ser quien propuso al cabildo catedral la realización de diversas modificaciones a la planta y alzado de la nueva iglesia, que había proyectado José Álvarez.

Las primeras noticias documentales sobre el arquitecto José Álvarez Mesa (1723-1800) se deben a Sancho Corbacho, quien manifestó que fue maestro mayor de casas del cabildo eclesiástico desde su nombramiento en 21 de octubre de 1765, maestro mayor de la catedral en 1775 y del arzobispado en 1782. De las iglesias diocesanas intervino en las de San Bartolomé (1779) y San Bernardo (17801785), de Sevilla; y en su provincia, en las parroquiales de Santa Cruz de Écija (1776) y de Aznalcóllar (1782). De la actual provincia de Cádiz documentó su participación en San Pedro de Jerez (1782), y en la de Huelva, en Santa Ana la Real (1783). Respecto a datos biográficos hay que destacar el hecho de que en un informe sobre la torre de San Pedro de Carmona, el arquitecto declara en 1785 que tenía 60 años, por lo que se infiere que pudo nacer en $1725^{9}$. Por nuestra parte hemos venido incrementando la nómina de edificios religiosos que proyectó, amplió o reformó, a través de diversas publicaciones. En 1979 aportamos que era natural de Huelva, según manifiesta en un examen de maestría del arte de albañilería, verificado en Sevilla en 1763. En dicha acta declara tener 32 años, por lo que estimamos que debió nacer en 1731. Asimismo especifica que es "alto de cuerpo, moreno, pelo castaño, ojos pardos, cerrado de barba, con una cicatriz en ella"10. En Sevilla capital documentamos sendos informes sobre las iglesias del Sagrario (1772) y Santa Ana (1784), así como la restauración que llevó a cabo en el Salón del Trono del Palacio arzobispal (1784) ${ }^{11}$. Asimismo publicamos que proyectó en esta ciudad la casa de don Benito del Campo, caballero veinticuatro y procurador mayor de Sevilla. Se edificó entre 1771-1775 en la calle San José 13, frente al convento de Madre de Dios, en la collación de San Nicolás. El edificio es ahora una de las sedes de la Consejería de Cultura de la Junta de Andalucía ${ }^{12}$. Mayor participación tuvo en las actuales provincias de Cádiz y Huelva. En la primera destacamos su labor en las iglesias de Algodonales (1773) y Puerto Serrano

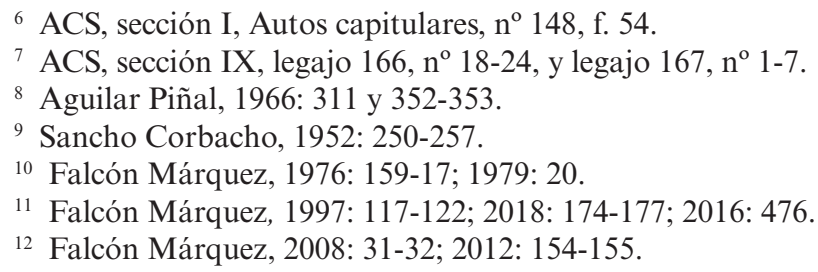


(1775); en la de Huelva, en Escacena (1768), Chucena (1773), Manzanilla y San Juan del Puerto (1782), Aracena, El Castaño del Robledo y El Cerro de Andévalo (todas ellas en 1783) y Alosno (1784) ${ }^{13}$. En aportaciones más recientes otros historiadores han documentado su intervención en las iglesias de El Ronquillo (Sevilla) en $1775^{14}$ y en la de Paradas (Sevilla), desde 1783 a $1785^{15}$, además del reconocimiento de haciendas y casas ${ }^{16}$.

Importantes han sido asimismo las aportaciones de Higuera Meléndez. Ahora sabemos que Álvarez nació en Huelva el 25 de abril de 1723, siendo bautizado el 31 de octubre en la iglesia parroquial de San Pedro. Era hijo del maestro albañil Juan Álvarez. En esa localidad aprendió el oficio con su primo Juan Clemente Álvarez. Con posterioridad, establecido en Sevilla se casó en la iglesia del Salvador con María Vicenta Sanguino el 8 de septiembre de 1750, con quien no tuvo descendencia. Superado el examen de maestro del arte de la albañilería en 1763, desarrolló una gran actividad en la diócesis de Sevilla tras los estragos del terremoto de 1755. Entre las obras que cita destacaremos su intervención en las iglesias de Chucena (1772-1773), Moguer (1776-1786), Santa Cruz de Écija (1776), San Bernardo de Sevilla (1780-1785), Aznalcóllar (1782), Villanueva del Ariscal (1776-1791), Linares de la Sierra (1782-1783) y San Sebastián de Marchena (1784). Testó ante el escribano Manuel Montero de Espinosa el 17 de febrero de 1793, falleciendo en Sevilla el 1 de octubre de 1800, a causa de la fiebre amarilla. Fue enterrado en la iglesia parroquial de la Magdalena ${ }^{17}$.

Aunque Sancho Corbacho manifestó que desde 1782 ostentó el cargo de maestro mayor del arzobispado de Sevilla, nunca tuvo oficialmente ese nombramiento. En su testamento se titula maestro mayor de obras de albañilería de la catedral de Sevilla, lo mismo que en la mayoría de sus informes. Lo que ocurrió es que a causa de la ruina total o parcial de numerosos templos diocesanos por el seísmo de Lisboa, actuó como maestro mayor en funciones, y por estar vacante ese oficio. Como tal figura en 1782 en un informe sobre la iglesia de Algodonales y dos años después en sendos reconocimientos de las iglesias de Alosno y El Castaño del Robledo. Del mismo modo cuando en 21 de enero de 1784 reconoció la iglesia de Santa Ana de Triana, se titula maestro mayor de la catedral y del arzobispado $^{18}$. Ante la ausencia de arquitectos titulados por la Real Academia de Bellas Artes de San Fernando, el gremio de alarifes sevillanos siguió teniendo importante protagonismo en la construcción local, como sucedió con José Álvarez,

${ }^{13}$ Falcón Márquez, 1977a: 22, 26-28, 30-31, 37-43, 87-91 y 213-219; 1983:19-20, 3940, 46, 114-116, 122, 128,136-138 y 140-146; 1983b: 90-91; 1986: 49-66; 2009: 49-66.

${ }_{14}$ Ollero Lobato, 1988: 49-66.

15 Pastor Torres, 1991: 151-160.

16 Ros González, 1999:14-39.

17 Higuera Meléndez, 2016: 353-384.

${ }_{18}$ Falcón Márquez, 2016: 376. 
que fue alcalde alarife en 1767 y examinador en el gremio de albañilería durante los años de 1766 y 1768, así como maestro mayor de la catedral desde $1775^{19}$. Desde que lo manifestó Sancho Corbacho se viene insistiendo que Álvarez fue entre sus contemporáneos el menos influido por la Academia. Lo cierto es que el repertorio ornamental neoclásico lo reservó para los entablamentos de los interiores de los templos, a base de entablamento dórico, con triglifos y metopas. Lo empleó en las iglesias de Nuestra Señora de Consolación de Aznalcóllar (1782), en la de San Juan Bautista de Linares de la Sierra (1783) y en San Bernardo de Sevilla (1780-1785). Respecto a los exteriores utilizó los característicos remates cerámicos de la época, como figuran en la sección de este templo, que publicamos ahora por primera vez. Cuando Álvarez presentó los proyectos de planta y sección longitudinal de esta iglesia en cabildo catedral de 10 de mayo de 1780, le faltaba un mes para cumplir 57 años, por lo que se trata de una obra de madurez. En las nóminas de oficiales y peones, quien percibía aquí una remuneración mayor era el aparejador, que estaba siempre a pie de obra. José Álvarez al margen de recibir sus honorarios por los proyectos, cobraba solo 3 reales diarios, por supervisar las obras y las cuentas de su equipo ${ }^{20}$. Como veremos particularmente en este templo, su obra evidencia que conocía a diversos tratadistas de la Arquitectura, especialmente a Sebastián Serlio y a fray Lorenzo de San Nicolás. Asimismo siguió la estela de la obra de arquitectos locales, como Leonardo de Figueroa y Pedro de Silva, en sendas estéticas del barroco polícromo.

Aportamos por primera vez que el aparejador que trabajó aquí con Álvarez fue Fernando Rosales. Del aparejador y arquitecto Fernando Rosales Ramos (1755-1830) las primeras noticias documentales se deben asimismo a Sancho Corbacho, quien facilitó datos sobre su formación como alumno en la Real Escuela de las Tres Nobles Artes de Sevilla en 1778, año en el que obtuvo el primer premio en un certamen por el proyecto de un edificio para Academia. Según este historiador, en 1786, un año después de la conclusión de la iglesia de San Bernardo, era ya arquitecto diocesano, aunque hasta 1795 no alcanzó el título de maestro mayor de fábricas del arzobispado. Informó sobre la iglesia de la Magdalena de El Arahal (1786) y sobre la de Chucena (1791). En la capital destaca el proyecto de la capilla de la Escuela de Cristo, ubicada dentro del recinto de la actual parroquia de Santa Cruz (1796-1801) ${ }^{21}$. Por nuestra parte aportamos su intervención en la construcción del marco arquitectónico de la portada de la Asunción, en la

19 Ollero Lobato, 2004: 193 y 199.

${ }^{20}$ ACS, Contaduría, legajo 12.316, exp. no 3: "Minuta de Álvarez. Reziví del Sr. Don Phelipe Neri de Monsalve [mayordomo de la Fábrica] setenta y ocho rs. de vn. por 26 días de trabajo de la obra de San Bernardo. 28 de febrero de 1781 [Firmado y rubricado: Joseph Álvarez]". ACS, Contaduría, legajo 12.316, exp. n 4: "Minuta de 31 de enero de 1782: Percibió 87 rs. de vn. por 29 días, a razón de 3 rs. cada día”.

${ }^{21}$ Sancho Corbacho, 1952: 263, láms. 214-215. 
catedral (1827-1831) ${ }^{22}$. En 1805 intervino en la construcción del pabellón suroeste de ese templo (antigua Sala de Rentas) ${ }^{23}$. Mayor actividad tuvo Rosales en iglesias diocesanas. En la actual provincia de Huelva documentamos su participación en la iglesia de Manzanilla (1784); en la de Alosno (1785), en donde se titula maestro mayor de fábricas de las iglesias de la ciudad de Sevilla y su arzobispado; en Cortegana (1794) y en Villanueva de los Castillejos (1799) ${ }^{24}$. En la provincia de Cádiz en los templos de Algodonales (1785), Puerto Serrano (1792) y Villamartín (1793-1809) 25 .

Ollero Lobato ha aportado nuevos datos. Entre ellos su formación en la Escuela de las Tres Nobles Artes, en la que fue nombrado en 1801 teniente de arquitectura y director titular en 1820. Respecto a la arquitectura religiosa publicó documentos sobre su intervención en Sevilla en la iglesia de San Bartolomé (17941796) y en la capilla de la Escuela de Cristo (1796-1801). En 1816 proyectó seis planos para la construcción de las iglesias de Santa Cruz y Santa María Magdalena, edificios derribados durante la invasión francesa. Participó en la iglesia de San Eutropio de Paradas (1785-1792), en la parroquia de El Arahal (1786), en Santa María de las Nieves de Los Palacios (1790-1796) y en la iglesia parroquial de Camas (1794). En la provincia de Huelva intervino en las iglesias de Villanueva de las Cruces (1784) y Alájar (1787). En la de Cádiz, en San Mateo de Jerez (17951796) ${ }^{26}$. Asimismo aportamos que informó sobre las murallas de esa ciudad y de su colegiata (hoy catedral) ${ }^{27}$. Respecto a la arquitectura civil destacaremos el proyecto de reforma (1806) de una casa en Sevilla para doña Antonia Pérez, situada en la calle Santa María la Blanca $\mathrm{n}^{\circ} 17$, con un remate de terraza de tipo gadi$\operatorname{tano}^{28}$. Como adelantamos, participó en la iglesia de San Bernardo como aparejador, estando al frente de las obras y de los operarios de principio a fin, tanto en las tareas constructivas como en la realización de los retablos, lo que evidencia que era un hombre de confianza de Álvarez. Cuando se iniciaron estas obras tenía 25 años. Percibía entonces 10 reales de vellón, y a partir de $1781,12^{29}$. Asimismo trabajó en esta obra como peón su hijo Juan José, desde los inicios, percibiendo 7 reales y medio ${ }^{30}$. A partir de 1775 hasta 1785 consta en las matrículas

${ }^{22}$ Falcón Márquez, 1981: 97.

${ }^{23}$ Luna Fernández-Aramburu/Serrano Barberán, 1986: 46, nota 114. Hernández Núñez, 1993: 121-142.

${ }^{24}$ Falcón Márquez, 1977a: 29-30, 32, 45, 47, 135-137 y 240-255.

${ }^{25}$ Falcón Márquez, 1983a: 30-31, 151-156 y 240-255.

${ }^{26}$ Ollero Lobato, 2004: 383-403.

27 Falcón Márquez, 1993: 177-197.

${ }_{28}$ Ollero Lobato, 2004: 302. Falcón Márquez, 2008: 22-23.

${ }^{29}$ ACS, Contaduría, legajo 12.316, exp. $\mathrm{n}^{\circ} 2$ y 3.

${ }^{30}$ ACS, Contaduría, legajo 12.316, exp. no 2. Minuta de 22 de junio de 1780. Se le cita como Joseph de Rosales, y en la nómina de 26 del mismo mes como "el hijo". Percibía 10 reales. 
de la Escuela de las Tres Nobles Artes ${ }^{31}$. Padre e hijo informaron en 1820 en un proyecto de reforma de la plaza del $\operatorname{Pan}^{32}$. Otro hijo que colaboró con él fue Alejandro Rosales, quien figura en una minuta en las obras finales de este templo ${ }^{33}$. Todo ello permite evidenciar que la construcción del templo de San Bernardo se convirtió en un campus y taller de formación de futuros constructores.

\section{LOS PLANOS Y MATERIALES CONSTRUCTIVOS}

El edificio se halla sobre una alta plataforma, con acceso por escalinatas hacia las dos portadas, sur y oeste. Esa elevación se debe sin duda para evitar los efectos de las inundaciones periódicas del Tamarguillo y del Guadalquivir. Precisamente cuando se iniciaba la construcción del templo, tuvo lugar la gran riada de 1783, de la que conocemos detalles por el erudito y académico Cándido María Trigueros, autor del poema La Riada ${ }^{34}$. En la publicación se indica que el agua subió 8 varas $(6,64 \mathrm{~m})$, siendo la mayor crecida del río conocida hasta entonces. Entre otros edificios afectó a la vecina Fábrica de Artillería ${ }^{35}$. Ya dijimos que el proyecto del nuevo templo de José Álvarez se mostró en cabildo catedral de 10 de mayo de 1780. Consta de planta y sección longitudinal. Lo complementó con un pliego de condiciones, fechado en 23 de mayo, evaluándose el presupuesto inicialmente en 520.000 reales de vellón ${ }^{36}$. Lo cierto es que el costo total, como diremos al final, fue casi el triple; ascendió a 1.404.306,10 reales de vellón, sin contabilizar lo que costaron los retablos y esculturas. Por las trazas percibió el arquitecto 400 reales de vellón ${ }^{37}$. El cabido las aprobó dos días después, presentando algunas modificaciones. Entre ellas que se ampliara la planta, prevista en 40 varas de largo $(33,20 \mathrm{~m})$, en 5 varas más $(37,35 \mathrm{~m})$. Asimismo para darle mayor regularidad al edificio se propuso que sustituyera cuatro columnas por sendos pilares, como el resto de los soportes. Son de planta rectangular, decorados con pilastras y traspilastras toscanas. Se trata de una iglesia de planta rectangular, de tres naves y testero plano. No tiene la orientación litúrgica tradicional, ya que es sur-norte.

${ }^{31}$ Ollero Lobato, 2004: 383, nota 1.

32 Ollero Lobato, 2006: 85.

${ }^{33}$ ACS, sección IV, 05206, f. 493r. En la minuta fechada en diciembre de 1786 consta: "De 25 alisares y 12 cargas de polvo de ladrillo pagado a Francisco Vidal según recibo y razón dada por el maestro Álvarez y Alexandro Rosales, que estaba por pagar y no se incluyó en la quenta de la obra, 43,4 rs. vn."

${ }^{34}$ Tiene como subtítulo Descríbese la terrible inundación que molestó a Sevilla en los últimos días del año 1783 i los primeros de 1784. Con licencia en Sevilla, en la Oficina de Vázquez y Cía. Año MDCCLXXXIV.

${ }^{35}$ Canto V, p. 86.

${ }^{36}$ ACS, sección IX, legajo 10.967, exp. 8.

${ }^{37}$ Higuera Meléndez, 2016: 368-369 y 382. 
Según el proyecto inicial iba ser de proporción dupla (40 x 20 varas); al incrementarse la longitud en 5 varas más, resultó más alargada y fuera de esa proporción. Según el pliego de condiciones, la nave mayor debía medir 9 varas de ancho $(7,87$ $\mathrm{m})$ y las laterales $5(4,15 \mathrm{~m})$. El templo ocupa en la actualidad la mitad de una manzana, delimitada a los pies por la calle Santo Rey; al lado del evangelio por la del Santísimo Cristo de la Salud, y tras la cabecera por la calle Alonso Tello. El resto, que da a la calle Marqués de Estella, la ocupan una serie de viviendas adosadas a dependencias parroquiales. La planta original que se conserva muestra algunas modificaciones con lo edificado ${ }^{38}$ (Figura 1). Accediendo por la puerta de los pies se ubica la torre $\left(n^{\circ} 7\right)$ a la izquierda y, en el lado opuesto ( $\left.n^{\circ} 8\right)$, estaba previsto para capilla bautismal. La pila se ha trasladado recientemente a la cabecera de este lado. Los mayores cambios se perciben en el entorno de la capilla mayor. Los $n^{\circ} 5$ del plano corresponden a las capillas colaterales. En la de la izquierda se halla la sacramental y al otro lado la de la Virgen de Patrocinio, que hace en la actualidad las funciones de la bautismal. Según se aprecia en el plano se redujo sensiblemente el espacio destinado a la capilla del Santísimo y sus dependencias $\left(n^{\circ} 6\right)$. Figura tras la capilla mayor, ocupando dos tramos. Se comunicaba con la capilla del testero, lado del evangelio, con el porche y con las "Casas de la Hermandad del Santísimo y de la Quincena”.

Debemos tener presente que cuando se planificaba la construcción del nuevo templo, se solicitó a la hermandad sacramental que cediera terrenos de su propiedad para la ampliación del espacio de la nueva iglesia. Para tal fin la hermandad cedió el espacio de su capilla, la sala de cabildos y demás dependencias, además de una serie de casas de su propiedad, inmediatas al templo. A cambio, el presidente de las capillas de la catedral se comprometía a edificar una nueva capilla, la sala de juntas y almacenes, así como bóveda de entierros, y la colocación de sus altares e imágenes en el nuevo templo. Se conserva una carta, sin fecha (1785), remitida por José Asensio, mayordomo de la hermandad Sacramental y Ánimas Benditas, al canónigo magistral, en la que denuncia el perjuicio ocasionado por la construcción de la nueva iglesia. Manifiesta que para la extensión del templo se cedió "su capilla, sala capitular y demás oficinas [...] con lo que se ha reducido la capilla a un tercio de lo que era, y además tiene que afrontar nuevos gastos para ubicarse en el nuevo templo" 39 . Fuera de él, en las dependencias anexas al lado de la epístola se proyectaron: la vivienda del párroco, con su patio ( $\left.\mathrm{n}^{\circ} 15\right)$; la del sacristán ( $\left.\mathrm{n}^{\circ} 11\right)$, que ha sido sustituida por un salón, y patio de enlace con la sacristía y archivo ( $n^{\circ} 14$ y 9). Se mantienen los porches $\left(n^{\circ} 20\right)$, protegidos por rejas, a los pies y en el lado del evangelio. El n ${ }^{\circ} 17$ era un espacio que había sobrado del solar de las dos casas que se habían incorporado al nuevo templo. Ese espacio, que se sugirió ofrecer a la Real Fundición, es actualmente la calle del Santísimo

\footnotetext{
${ }^{38}$ ACS, Fondo Capitular, sección Materiales especiales, $\mathrm{n}^{\circ} 619$.

39 ACS, Contaduría, leg. 12.316, exp. nº 1. De la Campa Carmona, 1992: 30.
} 
Cristo de la Salud. El n ${ }^{\circ} 18$ muestra cómo era inicialmente de estrecha esta calle. En las condiciones se establece también que esta fachada lateral de la iglesia, lado del evangelio, debería estar alineada con la fábrica de Artillería.

La sección longitudinal proyectada por Álvarez tiene como leyenda: "Alsado interior de la Iglesia y Capilla del Santísimo que anota o demuestra la letra A"40 (Figura 2). Al pie figura la firma y rúbrica del arquitecto. En ella se aprecian los tres tramos del cuerpo de la iglesia con las columnas de orden toscano previstas, sobre plintos, y coronadas con cimacios. El edificio tiene coro alto a los pies; el teórico crucero iba a cubrirse con bóveda vaída, en lugar de la cúpula y linterna que se construyó. Tras la capilla mayor se halla la de la sacramental (A), prevista inicialmente de un tramo. Los arcos son semicirculares, con ménsulas en las claves. En el entablamento, a eje con las columnas, había previsto una decoración de pinjantes, que daban una nota barroca, en lugar del friso neoclásico con triglifos que se ejecutó. Este modelo de pinjantes perdura al exterior de la cabecera del templo. Volviendo al interior, sobre el entablamento se aprecian las ventanas y lunetos. La nave central tiene cubiertas a dos aguas. En el proyecto se habían previsto remates cerámicos con esferas. Por el interior la nave central se cubre con bóveda de cañón, y las laterales con vaídas con lunetos, separadas por dobles arcos fajones. Los brazos del crucero son de bóveda de cañón. La capilla sacramental es de dos tramos, se cubre con sendas bóvedas semiesférica y vaída. Son interesantes las portadas neoclásicas que comunican las capillas colaterales con la mayor. Se decoran a base de pilastras toscanas y frontón rectangular con pinjantes y remates de perfil piramidal.

En las condiciones dadas por Álvarez en 10 de mayo de 1780 sobre la construcción del templo, se especifica que se hiciera una zanja para los cimientos "hasta lo sólido del terreno, lo preciso, teniendo presente que se ha de construir bóvedas subterráneas en la nave mayor y crucero [...] que serán de 4 a 5 varas de profundidad [de 3,32 a 4,15 m] y puesto en lo firme y sólido del terreno, se nivelará y se sigue el relleno de hormigón a tongas pisadas y retendidas, se echarán hiladas de piedras" $"$. Las obras se iniciaron a comienzos de junio de ese año, sacando los escombros del derribo del edificio anterior y comenzando a excavar los cimientos, labor que tuvo considerables problemas por la altura del nivel freático del agua. Las piedras para el relleno de los cimientos se trajeron de Alcalá de Guadaira y "de la Isla" (San Fernando) ${ }^{42}$, en barcazas por el río, que descargaban

${ }^{40}$ ACS, Fondo Capitular, sección Materiales especiales, $n^{\circ} 618$.

${ }^{41}$ ACS, Contaduría, legajo 12.316, exp. nº 1. Las bóvedas subterráneas (cripta) han sido habilitadas recientemente como columbario para las cenizas de los hermanos difuntos. Su bendición tuvo lugar el 21 de octubre de 2014.

42 ACS, Contaduría, legajo 12.316, exp. no 2. "Mes de agosto de 1780: Por las medidas para la construcción de los cimientos nuevos para dicha obra, 217 rs. A Jerónimo Ligero por quenta de la piedra para los simientos, 1.000 rs. A Pedro Barrera por quenta de 
al pie de la Torre del Oro y en "el Patín" (de las Damas, sector de la Barqueta) ${ }^{43}$. Consta que la primera piedra se puso el 21 de agosto de 1780 en el lugar donde se edificaría la torre, así como que el 4 de octubre de ese año se colocó el primer ladrillo para hacer uno de los pilares torales que iban a soportar la cúpula ${ }^{44}$. Los cimientos de la sacristía se iniciaron en septiembre de $1782^{45}$.

Respecto a la solería, en las condiciones dadas por el arquitecto proponía inicialmente que fuera de ladrillo cortado, de junto. Sin embargo cambió de criterio tres años después. En un informe presentado en 6 de julio de 1783 manifestó que este tipo de solería, como la que tenía la iglesia de San Roque, su coste ascendería a 5.000 reales de vellón, sin incluir el valor de la cal, y su ejecución; también subraya el frecuente desgaste de ese material, que obligaba a renovarlo periódicamente. Por todo ello propuso sustituirlo por losas de mármol de Génova, blancas y negras, como las que tenía la iglesia de San Pablo (la Magdalena). Evaluaba que serían precisas 12.500 piezas de 11 o 12 pulgadas, cuyo coste inicial sería de 26.250 reales, cantidad a la que había que añadir el transporte del material desde el embarcadero del río a la iglesia, además de cortarlo y bruñirlo, lo que ascendería a 30.250 reales. El arquitecto estimaba que esta solería sería "eterna"46. En cabildo catedral de 20 de abril de 1784 presentó el canónigo magistral y presidente de las capillas los gastos ocasionados por 14.300 losas de mármol procedentes de Génova. En el informe figuran los tipos de embarcaciones que transportaban, sus

siete partidas de piedra del río, 100 rs. Pagué por la piedra del Patín y Torre del Oro para los cimientos 1.747 rs. Pagué por quenta 1.705 quintales de piedra de Alcalá, 2.206,16. En 28 de agosto a seis peones que se quedaron sacando agua de los simientos el día 27, 24 rs. Están resividos en la obra de la Iglesia de San Bernardo asta el día 19 de agosto 839 quintales de piedra de Alcalá, a onze quartos el quintal, que a once reales vellón, mil ochenta y seis reales y 14 mrs. [Firma de José Álvarez]. Sr. Don Felipe Neri Monsalve, pagará usted a don Juan de Dios, capellán del Sr. canónigo don Ignacio Domonte, mil setesientos quarenta y siete reales de vellón en plata, que importan los 1.165 quintales de piedras de la Isla, que e recibido en la obra de la Iglesia de San Bernardo, a presio de uno y medio el quintal. Sevilla, 25 de agosto de 1780. José Álvarez". ACS, Contaduría, legajo 12.316, exp. $\mathrm{n}^{\circ}$ 3: "Marzo de 1781. Cuenta de los portes de tierra, granza (cascotes), piedra, arena, que a conducido y sacado del campo Joseph Cuello en la obra de la Iglesia de San Bernardo el año de 1780. Son 62.874 rs."

${ }^{43}$ ACS, Contaduría, legajo 12.316, exp. $\mathrm{n}^{\circ} 3$. Aquí constan numerosas minutas suscritas por Rosales por las barcazas de piedra que se trajeron en 1781 de la Isla. Suárez Garmendia, 1988: 199-213.

${ }^{44}$ Archivo de la parroquia San Bernardo (APSB), Nota inserta en el Libro de bautismos que comienza en 1784 , f. 20 r.

45 ACS, Contaduría, legajo 12.316, exp. no 4. "Quenta de la obra de la iglesia de San Bernardo del mes de septiembre de 1782. Sacó el señor Pedro Barreda setesientos quarenta portes de tierra de los cimientos de la sacristía de la obra de la iglesia de San Bernardo a presio de 6 mrs. cada porte. Septiembre 12 de 82". Firmado y rubricado por Rosales.

${ }^{46}$ ACS, Contaduría, legajo 12.316, exp. $\mathrm{n}^{\circ} 1$. 
nombres y los de sus capitanes. Al montante hubo que añadir 4.009,31 maravedíes que hubo que pagar en la Aduana ${ }^{47}$. Debemos recordar que desde comienzos del siglo XVI se traían a casas-palacio e iglesias andaluzas columnas, portadas, fuentes y solerías de mármol blanco, así como retablos funerarios, con materiales procedentes de las canteras de Carrara, labradas en Génova, además de losetas negras de la cantera de Lavagna (provincia de Génova). Entre algunos de los ejemplos más representativos de su empleo en esta región destacaremos en Málaga la casa de Diego de Cazalla (actual Museo Picasso) y en Sevilla la casa natal de Miguel Mañara, antigua casa de Juan de Almansa, una de las sedes de la Consejería de Cultura de la Junta de Andalucía, en la feligresía de San Bartolomét8.

En 27 de agosto de 1785 el maestro mayor de la catedral, Manuel Núñez, presentó una minuta por las obras de cantería finales, que para esta iglesia habían llevado a cabo una serie de canteros del templo metropolitano. Su costo ascendió a 11.414,26 reales de vellón. Entre ellas figuran piezas de jaspe encarnado para las gradas del presbiterio, pilas de agua bendita y aguamanil y para el solado de las bocas de bóvedas de entierro ${ }^{49}$. Por otra parte son muy numerosas las partidas de millares de ladrillos, que desde 1780 a 1784 se trajeron para los muros, bóvedas, cúpula, torre y portadas. Procedían principalmente de los hornos trianeros de José Sánchez y de Francisco y Miguel Vidal. Según su uso para la construcción de muros y bóvedas o para la decoración, se citan ladrillos comunes, raspados, delgados toscos, y toscos y gruesos de 3 pulgadas $^{50}$.

${ }^{47}$ ACS, legajo 12.317, exp. n 2B: "Por 4.000 losas en el navío nombrado La Verdad, del capitán Miguel Taglierani Ragusa. Por 4.000 idem del navío La Esperanza, del capitán Miguel Pecovich Ragusea. Por 4.300 idem en la polacra Ntra. Sra. del Rosario, del capitán Antonio Higgia Ragusea". La polacra es un barco de vela de dos palos, semejante al bergantín-goleta, con el palo de proa.

${ }^{48}$ Palomero Páramo, 1989: 385-400. Falcón Márquez, 2012: 94-99.

49 ACS, Contaduría, legajo 12.318, exp. n 1. "Quentas de la obra de la iglesia de Sr. San Bernardo, del mes de Noviembre de 1785".

${ }^{50}$ ACS, Contaduría, legajo 12.316, exp. $n^{\circ} 3$. Minutas de Rosales de septiembre de 1781: "E resevido del Sr. Don Joseph Sánchez desde el día 30 de abril asta el 30 de junio, seiscientos setenta y seis mil y trescientos ladrillos toscos gruesos y diesiocho mil ochosientos quarenta de tres purgadas con más de sesenta piezas de tres quartas y sinquenta y seis de media vara, todos en toscos y una carga de porvo de ladrillo para la obra de la Yglesia de San Bernardo. Julio Sevilla 12 de 1781. Rosales". "E resevido de Sr. Don Joseph Sánchez desde 23 de abril asta el día de la fecha treinta mil ochosientos sinquenta ladrillos comunes y tres mil setesientos sinquenta de tres purgadas para la obra de la Iglesia de San Bernardo. Abril 28 de 1781. Rosales". 


\section{EXTERIORES}

El enlucido de la fábrica de ladrillo, de color amarillo con vitolas, es moderno. Aunque estaba previsto inicialmente construirse una bóveda vaída en el teórico crucero, como figura en la sección longitudinal proyectada por Álvarez, lo cierto es que se edificó en su lugar una monumental cúpula con tambor y linterna, sin duda la última del barroco sevillano. Se erigió simultáneamente a la construcción de la torre, desde julio de 1782 hasta el mismo mes del año siguiente ${ }^{51}$. El arquitecto empleó un prototipo de Leonardo de Figueroa, de tambor cilíndrico por el interior y octogonal por el exterior, que había realizado en esta ciudad en la iglesia de San Pablo (la Magdalena). El modelo, a su vez, estaba inspirado en la lámina 178 del tratado de arquitectura de fray Laurencio (Lorenzo) de San Nicolás $\left(1^{\mathrm{a}} \text { parte }\right)^{52}$. Al exterior, en el tambor se abren cuatro ventanas semicirculares, rematadas en singulares frontones rotos. El resto están cegadas. El espacio cupuliforme se reviste de ocho paños de tejas curvas, de barro vidriado y policromado, que alternan colores blancos y azules. La linterna tiene ventanas enmarcadas por ocho pequeñas columnas de orden corintio, peraltadas sobre pedestales con decoración de azulejos, lo mismo que la pequeña cúpula que la cubre. Se remata con la tradicional cruz de forja de hierro y veleta, sobre una esfera de cobre. Por el interior los vanos del tambor se enmarcan con pilastras, lo mismo que los vanos cegados. El intradós de la cúpula muestra una decoración radial de ocho pilastras. De gran interés es la ornamentación de las pechinas, con lienzos que representan a los cuatro evangelistas; sus marcos están ricamente decorados con grandes molduras barrocas. Aunque no se especifica el nombre del tallista, tiene que ser José Arrés, el maestro carpintero que ejecutó el retablo mayor, según proyecto del maestro ensamblador Manuel Barrera y Carmona ${ }^{53}$. Aportamos como dato inédito que los lienzos de los evangelistas fueron realizados por el pintor Diego Suárez, entre julio y agosto de $1783^{54}$. De este artista se tenían escasas noticias ${ }^{55}$. Como veremos es quien pintó los remates de la cúpula y de la torre, así como retablos, puertas, herrajes, etc. En marzo de 1782 figura como maestro pintor y decorador, vecino de Sevilla, en la calle Naranjuelo, realizando el inventario post mortem de la marquesa del Casal. Llegó a ser alcalde del Noble Arte de

${ }^{51}$ ACS, Contaduría, legajo 12.316, exp. n 4 . En agosto de 1782, se iniciaron los pagos para la construcción de la cúpula, entre los que figuran numerosas partidas de puntales, azulejos e hierros. Estas últimas se deben al maestro herrero Pedro Márquez.

52 Falcón Márquez, 2007: 44-47.

${ }^{53}$ Roda Peña, 1988b: 206-221. Recio Mir, 2000: 129-147.

${ }^{54}$ ACS, Contaduría, legajo 12.317, exp. n 1: "120 rs. del tallista que conclulló [sic] las pechinas. Día 23 de julio de 1783”. Importe de los cuatro evangelistas con las cuatro molduras en una minuta suscrita por Diego Suárez en 25 de agosto de ese año.

${ }^{55}$ En 1783 percibió 1.260 rs. por el dorado y estofado del retablo de las Benditas Ánimas del Purgatorio en la iglesia de Santa Ana. Herrera García, 2016: 486-487. 
la Pintura, Dorado y Maqueado. El inventario a la muerte del comisario real de Guerra lo suscribió conjuntamente con los pintores José Huelva y Juan de Dios Fernández ${ }^{56}$.

La torre no figura en la sección longitudinal diseñada por Álvarez. Se ubica a los pies de la nave del evangelio, alineada con las dos fachadas. Es de fábrica de ladrillo. En las condiciones estipuladas por el arquitecto en 13 de mayo de 1780, manifiesta que el cuerpo de campanas "descoye (descuelle) por cima de los caballetes de la armadura de la iglesia, para que desparzan los ecos de las campanas". En cada una de las fachadas cajeadas de la caña se abren tres vanos, de distinto diseño, para iluminar la escalera interior. Los modelos son rectangulares con orejetas, óculos de perfil tetralobulado, de ascendencia de Leonardo de Figueroa, con remates mixtilíneos, y balcones culminados con un frontón triangular. El cuerpo de campanas sobre banco, presenta un vano en cada frente, flanqueado por pares de pilastras corintias; todo ello ornamentado con apliques de cerámica azul cobalto, lo que recuerda el cuerpo de campanas de la iglesia de San Roque, construido por Pedro de Silva entre 1760-1764 $4^{57}$. Sobre este cuerpo hay una terraza con antepechos ciegos con balaustres en relieve, que se coronan con remates piramidales y esferas. El conjunto culmina en un cuerpo octogonal, cubierto con una pequeña cúpula, sobre la que hay una cruz de forja de hierro. Además tuvo un giraldillo. La obra de fábrica de la torre estaba concluida en enero de 1783. A partir de entonces, hasta finales de agosto, el maestro herrero Pedro Márquez, presentó diversas minutas por las tareas que había ejecutado de balcones, crucetas, barandas y veleta ${ }^{58}$. En junio se puso el giraldillo y cuatro jarras de azucenas, tareas realizadas por el maestro latonero Miguel Payán, lo que parece evidenciar que era de silueta plana ${ }^{59}$, como el del artillero que remata una cúpula en la vecina fábrica de fundición. Todas estas piezas metálicas fueron pintadas en agosto de ese año por Diego Suárez ${ }^{60}$. Respecto a las campanas, en 27 de mayo de 1785

56 Illán Martín, 2006: 229-232.

${ }^{57}$ Sancho Corbacho, 1952: 255. Falcón Márquez, 1979: 30-31 y 72-73. Higuera Meléndez, 2016: 370, nota 53.

${ }^{58}$ ACS, Contaduría, legajo 12.316, exp. $\mathrm{n}^{\circ}$ 5. En la memoria presentada por Pedro Márquez en enero de 1783, figura la realización de una cruz para la torre, con su veleta, su valor $1.000 \mathrm{rs}$.

${ }^{59}$ ACS, Contaduría, legajo 12.316, exp. no 5. (al margen: Torre): "Junio de 1783. Digo yo Joseph Payán, maestro de latonero, que entregué a el Sr. Narciso Garabal y Sanguino un giraldillo, quatro ramas de azucenas y veinte y siete remates, todo ello de metal, lo qual he tasado su valor de esta forma: el giraldillo 150 rs. de vn., los quatro ramos de azucenas, 150 y los remates, 120 ".

${ }^{60}$ ACS, Contaduría, legajo 12.316, exp. no 5 . En una minuta presentada por Suárez en 20 de enero de 1783, figuran los gastos por la pintura de la veleta, de color verde y dorado, las dos tinajas y otras piezas en la torre y media naranja. ACS, Contaduría, legajo 12.317, exp. $\mathrm{n}^{\mathrm{o}}$ 1: "Importan los quatro evangelistas, con las quatro molduras, los remates 
consta un pago a Vicente Falcó por la ejecución de tres para esta torre ${ }^{61}$. Este fundidor hizo la "Santa Gertrudis" (campana chica) de la iglesia de San Pedro de Carmona en 1781, y en 1790 otras dos para la torre de la iglesia de San Eutropio de Paradas ${ }^{62}$. En 1792 Falcó se titula maestro fundidor de campanas de este arzobispado al realizar varias para la iglesia de Santa Ana, de Triana ${ }^{63}$. Años después, en 28 de junio de 1789, Francisco de la Rosa suscribió un recibí de "3.000 rs. de vn. en cuenta de los 6.000 rs. de vn. que se me debe entregar para la construcción de la campana que se está fundiendo para la torre de la iglesia del $\mathrm{Sr}$. San Bernardo" "64. Por otra parte hay que destacar las buhardillas que coronan el cuerpo de la iglesia, que sirven de ventilación del entramado de madera que soporta el tejado. Siguen el modelo creado por Leonardo de Figueroa en las iglesias de San Pablo (la Magdalena), el Salvador y San Luis, entre otras.

Respecto a las portadas, en las condiciones se estipula que han de ser "de ladrillo cortado en limpio". Se construyeron en 1783, realizándose su decoración a comienzos del siguiente año. La más interesante es la de los pies del templo, que se organiza a base de una superposición de arco y dintel, flanqueándose con columnas toscanas sobre altos pedestales, más traspilastras. Su entablamento es dórico, con triglifos y metopas. El frontón roto alberga una hornacina, enmarcada por columnas jónicas. En ella preside una imagen en barro cocido que representa al santo titular. Fue realizada por Cristóbal Ramos, quien en 5 de enero de 1784 percibió por ella 250 reales de vellón ${ }^{65}$. Este segundo cuerpo se decora con molduras convexas y roleos. Su frontón roto y enroscado alberga una maqueta de la Giralda, entre ramas de azucenas, blasón del cabildo catedral. Remata el conjunto un vano de ojo de buey que ilumina el interior del templo. La portada del lado del evangelio, más sencilla, se enmarca entre pilastras y traspilastras dórico-toscanas.

de azucenas, todo para la iglesia de San Bernardo, un mil ciento y quarenta y seis rs. de vn. Y por ser verdad lo firmo oy 25 de agosto de 1783. Diego Suárez".

${ }^{61}$ ACS, Contaduría, legajo 12.317, exp. $\mathrm{n}^{\circ} 3$.

${ }^{62}$ De la Villa Nogales/Mira Caballos, 1993: 221.

${ }^{63}$ Archivo General del Arzobispado de Sevilla (AGAS), sección 3 ${ }^{\text {a }}$, legajo 11095 (1255).

${ }^{64}$ ACS, Contaduría, legajo 12.318, exp. $\mathrm{n}^{\circ} 1$.

${ }^{65}$ Recio Mir, 2001: 155. ACS, Contaduría, legajo 12.317, exp. n 1: "Recibí del Sr. Don Felipe Neri Monsalve, 250 rs. de vn., que con doscientos que antes he recibido por mano de dicho Sr. Monsalve, hacen treinta pesos, por haber hecho la estatua del Sr. San Bernardo, para el nicho por encima de la puerta de la iglesia de San Bernardo, extramuros de esta ciudad, y por ser verdad lo firmé hoy 5 de enero de 1784 años. Cristóbal Ramos, 250 ducados". Según una minuta fechada en 16 de enero de ese año, suscrita por José Rosales, se pagaron "4 rs. de traer el aparejo para subir el santo". Según Hernández Díaz/Sancho Corbacho, 1936: 150: "El templo no ha sufrido deterioros de consideración durante los sucesos revolucionarios. Solo padeció la profanación inculta del populacho la estatua del santo titular de la portada principal, pero sin mutilaciones de importancia". 
En su frontón roto hay un penacho central. El tema está inspirado en una lámina del tratado de fray Lorenzo de San Nicolás $(1639)^{66}$. Los exteriores del templo presentan un porche en las fachadas sur y oeste, que está cerrado por una verja de hierro. Fue ejecutada por el maestro Pedro Márquez, quien realizó todo el herraje del templo: retablo mayor, cúpula, torre y casa rectoral, entre 1783-1784 ${ }^{67}$.

Están perfectamente documentados todos los gastos de la construcción del templo, desde junio de 1780 hasta abril de 1786 , que finalizaron ${ }^{68}$, por lo que las obras prosiguieron tras la bendición del templo en el verano anterior. Aquí se contabiliza el costo de los solares de casas que permitieron ampliar el recinto, los salarios de los oficiales y peones, así como los materiales constructivos y decorativos. Como este artículo está dedicado a la construcción del edificio, no tendremos presente el coste de los retablos, cuyas cuentas se iniciaron en 5 de febrero de 1780 .

De junio a diciembre de 1780 los gastos ascendieron a $.132 .755,22$

En 1781 “
En 1782 “
En 1783 “
En 1784 “
En 1785 “
En 1786 (de enero a abril) “
$350.897,09$ $245.999,31$ $280.709,13$ $187.834,01$ $166.111,06$ $.12 .498,31$

Total: $1.376 .804,08$

Los solares de casas incorporados en 1780 costaron: $27.502,02$

El montante total de la construcción ascendió a........ 1.404.306,10 rs. de vn.

En una nota inserta en el libro 14 de bautismos, se resume así el proceso constructivo del templo actual. El 28 de mayo de 1780 se inició el derribo del templo anterior. La primera piedra del nuevo edificio se puso el 21 de agosto de ese año, en el sitio previsto para la torre. El 4 de octubre se colocó el primer ladrillo en la base de uno de los pilares torales que iban a soportar la cúpula. Durante el curso de las obras se fueron habilitando diversas dependencias, retablos y demás piezas,

${ }^{66}$ De San Nicolás, 1639: 184-185. Falcón Márquez, 2007: 184-185.

${ }^{67}$ ACS, Contaduría, legajo 12.316, exp. no 5, febrero de 1783; legajo 12.317, exp. $\mathrm{n}^{\circ} 1$, noviembre-diciembre de 1783; legajo 12.317, exp. n $2 \mathrm{~B}$, febrero y junio de 1784. También se empedró el entorno de la iglesia. ACS, Contaduría, legajo 12.318, exp. $\mathrm{n}^{\circ} 1$, Cuentas de la obra de 17 de octubre de 1785 .

${ }^{68}$ ACS, Contaduría, legajo 12.316, exp. $\mathrm{n}^{\circ}$ 1, "Gastos hechos para la obra de la nueva Iglesia de San Bernardo". ACS, Contaduría, legajo 12.318, exp. n² 2, "Quenta de las obras de la iglesia en abril de 1786 en que se finalizó". 
comenzándose por el lado de la epístola. En abril de 1785 se destinó como retablo mayor el de la Virgen del Patrocinio, en la cabecera de esta nave, y el de la Encarnación como sagrario. El 18 de agosto se bendijo la nave mayor y la del evangelio, consagrándose el nuevo templo el día siguiente, víspera de la festividad del santo titular. La casa rectoral se inauguró el 5 de junio de 1787 por el nuevo párroco, Cristóbal García Marmolejo ${ }^{69}$.

El primer bautizo tuvo lugar el 28 de agosto de 1785. Se trata del de María Josefa Bernarda, hija de Miguel Téllez y de Sebastiana Ortiz. Fueron sus padrinos José y Juana Ortiz. La ceremonia fue oficiada por fray Pedro de Sopetrán, religioso agustino del convento del Pópulo, con licencia del párroco, don Antonio Lamela ${ }^{70}$. El texto concluye destacando el párroco la labor desarrollada en el transcurso de las obras por la hermandad Sacramental. La nueva casa hermandad se halla situada frente a la fachada principal del templo, en la calle Santo Rey 34. La primera piedra se puso en una ceremonia oficiada por el cardenal don Carlos Amigo Vallejo en noviembre de 2008. Tras su conclusión, fue bendecida el 19 de febrero de 2010 por el arzobispo don Juan José Asenjo Pelegrina.

\section{APÉNDICE DOCUMENTAL}

Leyenda de la planta de la iglesia de San Bernardo por José Álvarez.

[Presentada en cabildo catedral el 10-5-1780]

ACS, Materiales especiales, $\mathrm{n}^{\circ} 619$.

"Plano orisontal para Yglesia/ Parroquial del Sr. Sn. Bernardo extramuros de esta Ciudad.

$\mathrm{N}^{\mathrm{o}} 1^{\circ}$. Puertas pral. y segunda

$\mathrm{N}^{\circ}$ 2. Mesas de Altares los que ban demostrado con cruz

$\mathrm{N}^{\circ}$ 3. Nave Mayor y Presbiterio

$\mathrm{N}^{\circ}$ 4. Cruzero

$\mathrm{N}^{\circ} 5$. Naves coraterales y capillas

$\mathrm{N}^{\circ}$ 6. Capilla del Santissimo

$\mathrm{N}^{\circ}$ 7. Torre

$\mathrm{N}^{\circ}$ 8. Capilla Baptismal

$\mathrm{N}^{\circ}$ 9. Archivo

$\mathrm{N}^{\circ} 10$. Taca de Óleos

$N^{\circ}$ 11. Quarto de Sachristán con su Dormitorio

$\mathrm{N}^{\circ}$ 12. Patio de Luzes

$\mathrm{N}^{\circ} 13$. Oficinas comunes con patio

${ }^{69}$ De la Campa Carmona, 1992: 30-35.

70 APSB, Libro 14 de bautismos que comienza en 1784, ff. 20r y 21v, Bautizo no 52. 
$\mathrm{N}^{\circ}$ 14. Sachristia, Agua Manil y hueco para/cajonería

$\mathrm{N}^{\circ}$ 15. Casa del Padre cura con todas sus/oficinas, de salas, cosina y patio y estudio

$\mathrm{N}^{\circ} 16$. Entrada por la fachada a la casa

$\mathrm{N}^{\circ}$ 17. Sitio que se da a la R1. [Fundición de Artillería] si Vs. lo tuvieren/por conveniente

Que es spbte. [sobrante] de las casas comps. [compradas]

$\mathrm{N}^{\circ}$ 18. Calle de la Real Fundición

$\mathrm{N}^{\circ}$ 19. Sitio donde están las casas de la Hermandad/del Santissimo, y de la Veintena

$\mathrm{N}^{\mathrm{o}} 20$. Porches

Firmado y rubricado: Joseph Alvarez. Escala de 10 baras castellanas".

Fecha de recepción: 21 de octubre de 2019

Fecha de aceptación: 13 de abril de 2020

\section{BIBLIOGRAFÍA}

Aguilar Piñal, Francisco (1966): La Real Academia de Buenas Letras en el siglo XVIII: Madrid, CSIC.

Cabra Loredo, María Dolores (1988): Iconografía de Sevilla (1400-1650). Madrid: Ediciones El Viso.

Caro, Rodrigo (1634): Antigüedades y principado de la ilustre ciudad de Sevilla y corografía de su convento jurídico o antigua Chancillería. Sevilla: Andrés Grande.

Carriazo, Juan de Mata (1954): "Negros, esclavos y extranjeros en el barrio sevillano de San Bernardo (1617-1629)". En: Archivo Hispalense, 64-65, pp. 125133.

Collantes de Terán, Antonio (1977): Sevilla en la Baja Edad Media. La ciudad y sus hombres. Sevilla: Ayuntamiento.

Cruz Isidoro, Fernando (1995): Arquitectura sevillana del siglo XVII. Maestros mayores de la Catedral y del Concejo Hispalense. Sevilla: Universidad.

De la Campa Carmona, Ramón (1992): "La fábrica de la parroquia de San Bernardo". En: Tabor y Calvario, 18, pp. 30-35.

De la Vega Viguera, Enrique (1992): Sevilla y la Real Fundición de Cañones. Sevilla: Guadalquivir Ediciones.

De la Villa Nogales, Fernando/Mira Caballos, Esteban (1993): Documentos inéditos para la Historia del Arte de la provincia de Sevilla. Siglos XVI al XVIII. Sevilla: Cegal.

De San Nicolás, Fray Lorenzo (1639): Arte y uso de Architectura. Madrid: s. e., tomo I. 
Domínguez Ortiz, Antonio (1970): Orto y ocaso de Sevilla. Sevilla: Universidad. Espinosa de los Monteros, Pablo (1627): Historia, antigüedades y grandezas... de Sevilla. Sevilla: Oficina de Matías Clavijo.

Falcón Márquez, Teodoro (1976): "Pedro de Silva, arquitecto diocesano". En: Actas del I Congreso de Historia de Andalucía. Andalucía Moderna (siglo XVIII). Córdoba: Monte de Piedad y Caja de Ahorros de Córdoba, vol. I, pp. 159-172.

-(1977a): Documentos para la Historia de la Arquitectura Onubense. Huelva: Diputación Provincial.

(1977b): La Capilla del Sagrario de la catedral de Sevilla. Sevilla: Diputación Provincial.

(1979): "Pedro de Silva". Sevilla: Diputación Provincial.

(1981): La catedral de Sevilla. Estudio arquitectónico. Sevilla: Ayuntamiento/ Diputación Provincial.

(1983a): Iglesias de la Sierra de Cádiz. Cádiz: Caja de Ahorros Provincial. (1983b): Arquitectura barroca en Jerez. Jerez: Centro de Estudios Históricos Jerezanos/CSIC.

(1984): "Antecedentes sevillanos de iglesias fortificadas mexicanas". En: II Jornadas de Andalucía y América. Sevilla: Escuela de Estudios Hispanoamericanos, pp. 399-409.

(1996): Sevilla, puerto y puerta de América. Sevilla: Sociedad Estatal de Gestión de Activos, S.A. (AGESA).

(1997): El palacio arzobispal de Sevilla. Córdoba: Cajasur.

(2007): "San Nicolás, fray Laurencio. Arte y uso de Architectura". En: Libros del Fondo Antiguo del Laboratorio de Arte. Sevilla: Universidad, pp. 44 47.

(2008): La iglesia de San Nicolás de Bari. Una iglesia del siglo XIII en un templo barroco. Sevilla: Cajasol/ Diputación Provincial.

(2009): "La arquitectura en Andalucía al final del Barroco". En: Actas del Congreso Internacional Andalucía Barroca. Sevilla: Consejería de Cultura de la Junta de Andalucía, vol. I, pp. 49-66.

(2012): Casas sevillanas desde la Edad Media hasta el Barroco. Sevilla: Maratania.

(2016): "La iglesia de Santa Ana: de edificio fortificado a templo barroco". En: Santa Ana de Triana. Aparato histórico-artístico. Sevilla: Fundación Cajasol, pp. 363-381.

(2018): El palacio arzobispal de Sevilla. Historia y patrimonio. Sevilla: Archidiócesis.

(2019): "La iglesia de San Bernardo de Sevilla. De ermita fortificada a templo barroco". En: Laboratorio de Arte, 31, pp. 27-40.

Ferrín Paramio, Rocío (2009): El Alcázar de Sevilla en la Guerra de la Independencia. El Museo Napoleónico. Sevilla: Ayuntamiento de Sevilla. 
García Quilis, Manuel (1999): "El antiguo Cuartel de Caballería llamado «de la Carne»". En: Milicia y sociedad en la Baja Andalucía (siglos XVIII y XIX). Sevilla: Deimos, pp. 829-840.

Gestoso y Pérez, José (1892): Sevilla Monumental y Artística. Sevilla: Ayuntamiento, vol. 3.

González de León, Félix (1840): Noticia artística de todos los edificios públicos de esta muy noble ciudad de Sevilla. Sevilla: Imprenta de D. José Hidalgo y Compañía.

Halcón, Fátima/Herrera, Francisco/Recio Mir, Álvaro (2000): El retablo barroco sevillano. Sevilla: Universidad de Sevilla/Fundación El Monte.

(2009): El retablo sevillano desde sus orígenes a la actualidad. Sevilla: Diputación Provincial/Fundación Real Maestranza/Fundación Cajasol.

Hernández Díaz, José (1935): "Papeletas para la Historia del retablo en Sevilla durante la segunda mitad del siglo XVII". En: Boletín de Bellas Artes, 2, pp. 35-36.

Hernández Díaz, José/Sancho Corbacho, Antonio (1936): Estudio de los edificios religiosos y objetos de culto de la ciudad de Sevilla, saqueados y destruidos por los marxistas. Sevilla: Imprenta de la Gavidia.

Hernández Núñez, Juan Carlos (1993): "La construcción de las dependencias catedralicias del ángulo suroeste y su repercusión en el urbanismo sevillano". En: Archivo Hispalense, 233, pp. 121-142.

Herrera García, Francisco Javier (2001): El retablo sevillano en la primera mitad del siglo XVIII. Sevilla: Diputación Provincial.

Higuera Meléndez, José Manuel (2016): “José Álvarez (1723-1800), maestro mayor de obras del arzobispado de Sevilla”. En: Isidorianum, 25, pp. 353-384.

López Martínez, Celestino (1928a): Arquitectos, escultores y pintores vecinos de Sevilla. Sevilla: Rodríguez-Giménez y Cía.

(1928b): Retablos y esculturas de traza sevillana. Sevilla: Rodríguez-Giménez y Cía.

(1932): Desde Martínez Montañés hasta Pedro Roldán. Sevilla: RodríguezGiménez y Cía.

Luna Fernández-Aramburu, Rocío/Serrano Barberán, Concepción (1986): Planos y dibujos del Archivo catedral de Sevilla. Sevilla: Diputación Provincial.

Martínez Ripoll, Antonio (1978): Francisco de Herrera el Viejo. Sevilla: Diputación Provincial.

Mora Piris, Pedro (1994): La Real Fundición de bronce de Sevilla. Sevilla: Escuela Superior de Ingeniería.

Morales Sánchez, José (1991): La Real Fábrica de Tabacos. Arquitectura, territorio y ciudad en la Sevilla del siglo XVIII. Sevilla: Fundación Fondo de Cultura de Sevilla.

Morgado, Alonso (1587): Historia de Sevilla. Sevilla: Andrea Pescioni-Juan de León. 
Ollero Lobato, Francisco (1988): "La intervención de los arquitectos diocesanos del siglo XVIII en la iglesia parroquial de El Ronquillo”. En: Atrio, 0, pp. $35-46$.

(2004): Cultura artística y arquitectura en la Sevilla de la Ilustración (17751808). Sevilla: Caja San Fernando.

(2006): "La Sevilla soñada. Plazas y ciudad en los inicios del siglo XIX”. En: Atrio, 12, pp. 81-94.

Palomero Páramo, Jesús (1989): "Antonio María Aprile de Carona y la marmolería de XVII". En: Actas del III Coloquio Hispano-Italiano. La Rábida: CSIC, pp. 385-400.

Pastor Torres, Álvaro (1991): "Planos inéditos de la parroquia de San Eutropio de Paradas". En: Atrio, 3, pp. 151-160.

Peñalver Gómez, Eduardo (2005): "Civitates Orbis Terrarum”. En: V Centenario de la Universidad de Sevilla (1505-2005). Sevilla: Universidad de Sevilla/ Fundación El Monte.

Ponce Ortiz, Mercedes/Morales Sánchez, José (2004): Sevilla. Arquitectura y ciudad militar: El Cuartel de la Carne. Patrimonio Recuperado. Sevilla: Diputación Provincial.

Rabanal Yus, Aurora (1988): "El reinado de Carlos III en la arquitectura de las Reales Fundiciones Españolas”. En: Fragmentos, 12-14, pp. 103-113.

Recio Mir, Álvaro (1999): Sacrum Senatum. Las estancias capitulares de la catedral de Sevilla. Sevilla: Universidad de Sevilla.

(2000): "El final del barroco sevillano: Manuel Barrera y Carmona, Blas Molner y el retablo mayor de San Bernardo". En: Archivo Hispalense, 253, pp. 129-147.

(2001): "El escultor Cristóbal Ramos al servicio del cabildo de la catedral de Sevilla". En: Boletín de Bellas Artes, 29, pp. 155-159.

(2011): "Asensio de Maeda". En: Proyecto Andalucía. Arquitectos y artífices del Arte Andaluz. La Coruña: Publicaciones Comunitarias, tomo XXXVI, pp. 38-68.

Roda Peña, José (1988a): "Pedro Duque Cornejo en la Capilla Sacramental de la parroquia de San Bernardo de Sevilla”. En: Laboratorio de Arte, 11, pp. 571-583.

(1988b): "Manuel Barrera Carmona, retablista en la Sevilla de Carlos III". En: Archivo Hispalense, 217, pp. 206-221.

(1996): Las Hermandades Sacramentales de Sevilla. Una aproximación a su estudio. Sevilla: Ediciones Guadalquivir.

Roig del Negro, Álvaro (2001): La Real Fundición de Cañones de Bronce de Sevilla. Historia, arquitectura y urbanismo de una fábrica del siglo XVIII. El edificio como condicionante en la conformación del barrio de San Bernardo. Tesis doctoral. Sevilla: Escuela Técnica Superior de Arquitectura de la Universidad de Sevilla, 2001. 
Ros González, Francisco S. (1999): Noticias de Escultura (1781-1800). En: Fuentes para la historia del arte andaluz. Sevilla: Ediciones Guadalquivir, vol. 19. Sancho Corbacho, Antonio (1952): Arquitectura barroca sevillana del siglo XVIII. Madrid: CSIC.

Serrera, Juan Miguel/Oliver, Alberto (1989): Iconografía de Sevilla (1650-1790). Madrid: Ediciones El Viso.

Suárez Garmendia, José Manuel (1988): "El Patín de las Damas: un lugar olvidado". En: Laboratorio de Arte, 1, pp. 199-213.

Trigueros, Cándido María (1784): La Riada. Sevilla: Oficina de Vázquez y Cía.

Valdivieso, Enrique (2003): Pintura barroca sevillana. Sevilla: Ediciones Guadalquivir.

Valdivieso, Enrique/Serrera, Juan Miguel (1982): La época de Murillo. Antecedentes y consecuentes de su pintura. Sevilla: Diputación Provincial.

(1985): Pintura sevillana del primer tercio del siglo XVII. Madrid: Instituto Velázquez/CSIC.

Vera Aranda, Ángel L. (1988): "El barrio de San Bernardo (Sevilla)". En: Revista de Estudios Andaluces, 10, pp. 109-136. 


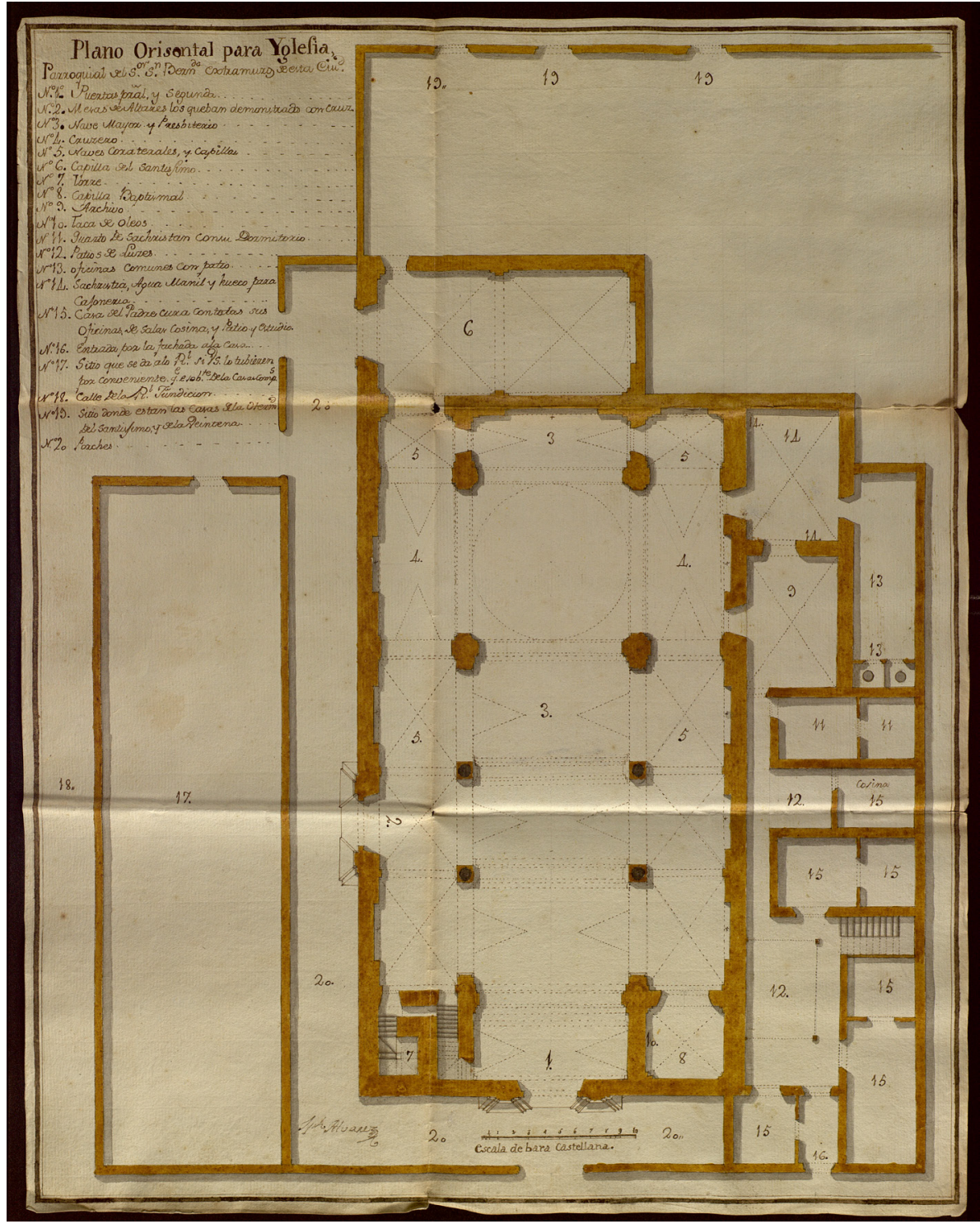

Figura 1. José Álvarez, Planta de la iglesia de San Bernardo, 1780. Institución Colombina, ACS, Fondo Capitular, sección Materiales especiales, nº 619. 


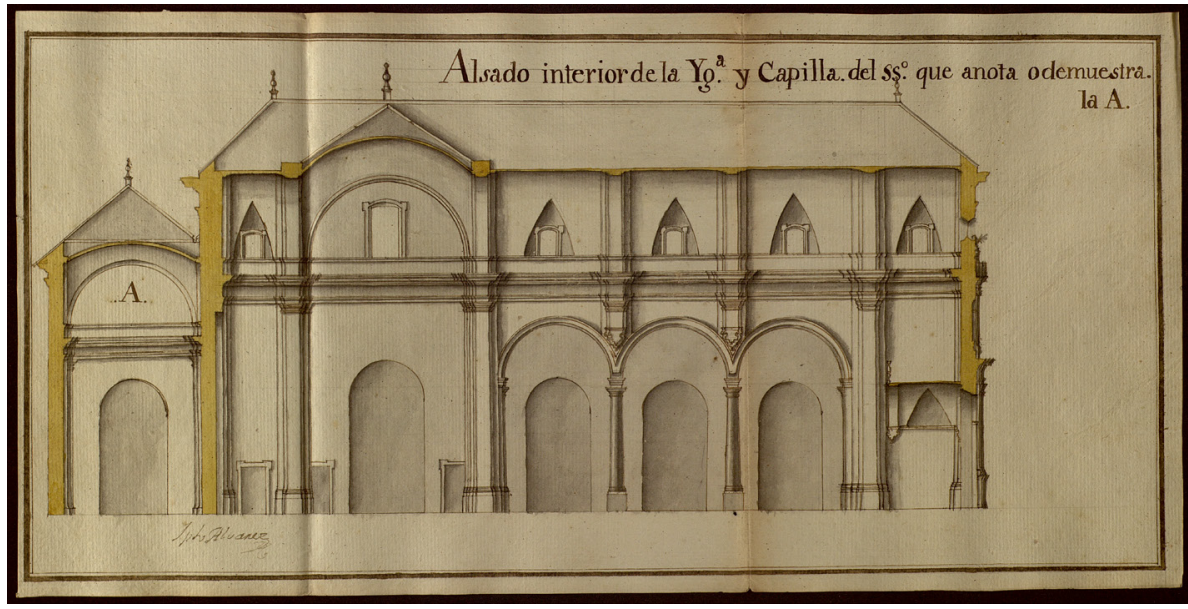

Figura 2. José Álvarez, Sección de la iglesia de San Bernardo, 1780. Institución Colombina, ACS, Fondo Capitular, sección Materiales especiales, nº 618.

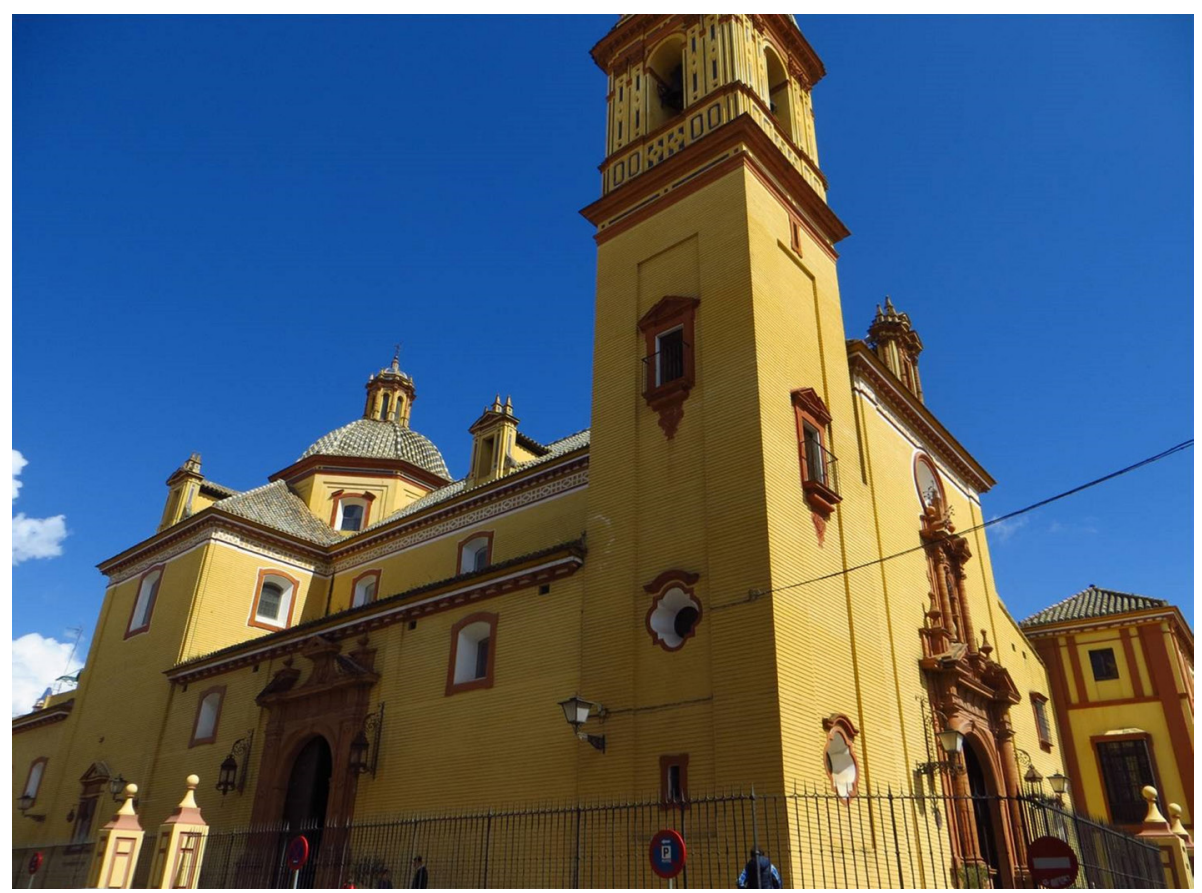

Figura 3. Vista exterior, iglesia de San Bernardo, Sevilla. 


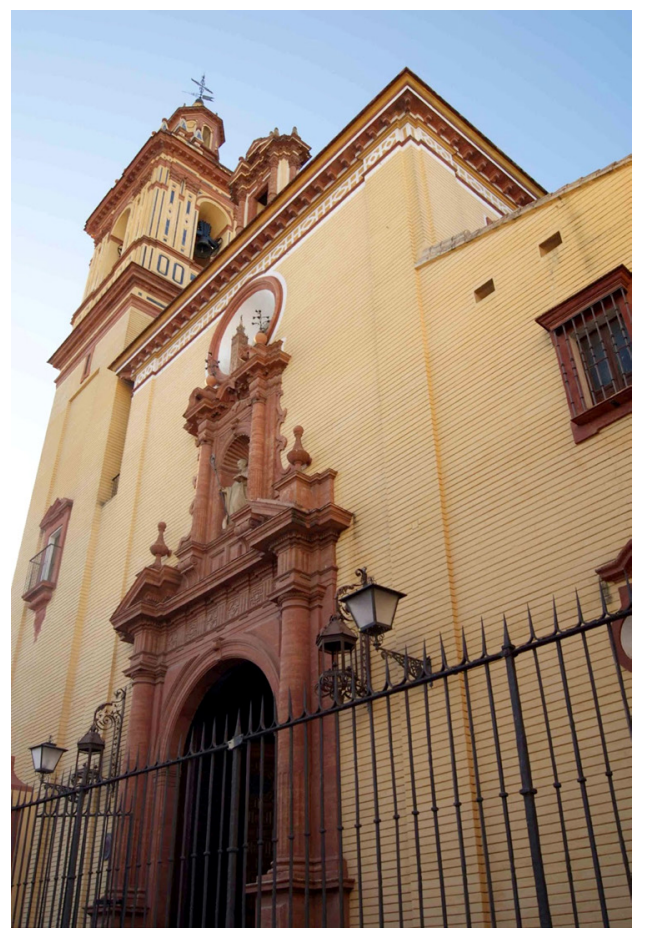

Figura 4. Fachada principal, iglesia de San Bernardo, Sevilla.

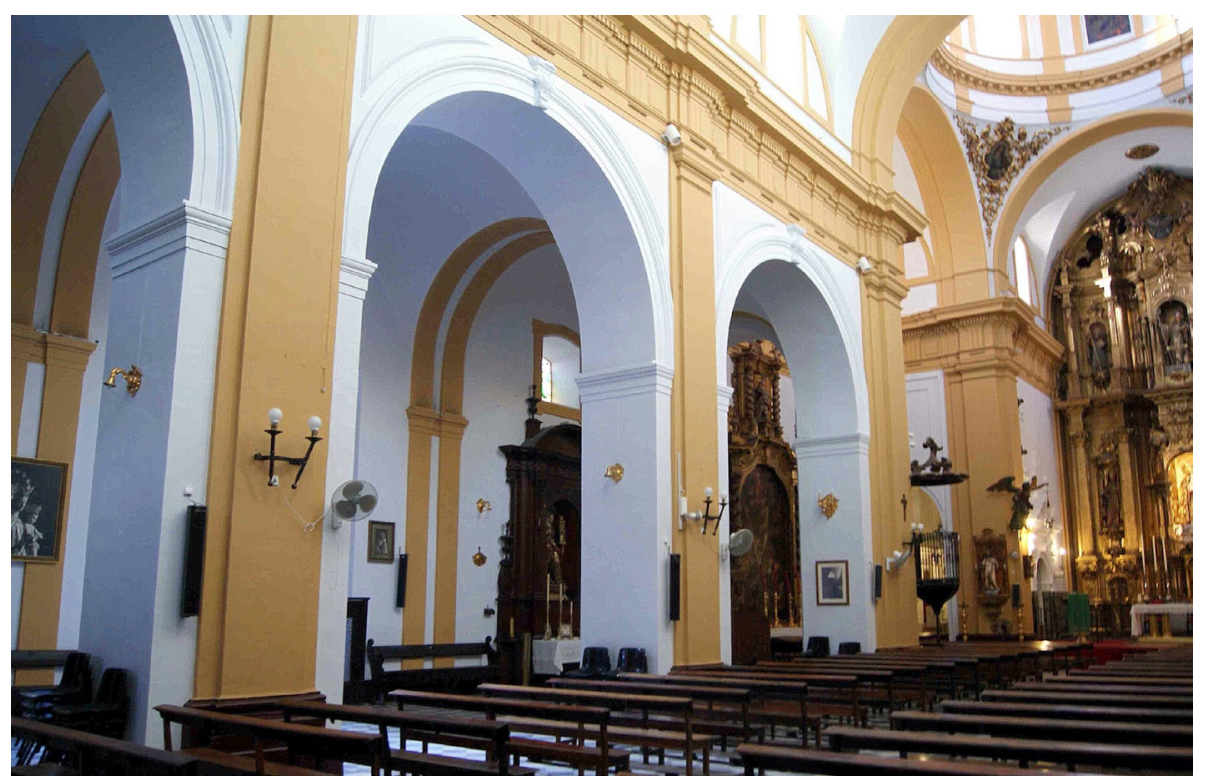

Figura 5. Vista interior, iglesia de San Bernardo, Sevilla.

LABORATORIO DE ARTE 32 (2020), pp. 95-118, ISSN 1130-5762 e-ISSN 2253-8305 - DOI http://dx.doi.org/10.12795/LA.2020.i32.06 